\title{
Antimicrobial Activity of Different Root Canal Filling Pastes Used in Deciduous Teeth
}

\author{
Fabiane Piva ${ }^{\mathrm{a} *}$, Italo Medeiros Faraco Junior ${ }^{\mathrm{b}}$, Carlos Estrela ${ }^{\mathrm{c}}$ \\ ${ }^{a}$ Curso de Odontologia, Universidade Luterana do Brasil - ULBRA, \\ Rua Martinho Lutero, 301, 96501-595 Cachoeira do Sul - RS, Brazil \\ ${ }^{\mathrm{b}}$ Curso de Odontologia, Universidade Luterana do Brasil - ULBRA, \\ Av. Farroupilha, 8001, Prédio 59, $3^{\circ}$ andar, 92425-900 Canoas - RS, Brazil \\ ' Departamento de Ciências Estomatológicas, Universidade Federal de Goiás, \\ Praça Universitária, CP 35, Goiânia - GO, Brazil
}

Received: October 12, 2007; Revised April 30, 2008

\begin{abstract}
The purpose of this study was to evaluate in vitro the antimicrobial activity of materials used as root canal filling in deciduous teeth by direct exposure test. The materials tested were: Guedes-Pinto, CTZ, zinc oxide eugenol, Calen ${ }^{\circledR}$, L\&C and MTA pastes. A microbial mixture was prepared with $1 \mathrm{~mL}$ each of pure suspension of the following microorganisms: Staphylococcus aureus, Enterococcus faecalis, Pseudomonas aeruginosa, Bacillus subtilis, Candida albicans. For the direct exposure test, sterilized paper points were contaminated with the microbial mixture suspension and placed in contact with the respective materials for 24,48 and 72 hours. At these intervals, paper points were removed and immersed in $7 \mathrm{~mL}$ of Letheen broth, followed by incubation at $37^{\circ} \mathrm{C} / 48$ hours. $100 \mu \mathrm{L}$ of inoculum obtained from Letheen broth was transferred to $7 \mathrm{~mL}$ of BHI under identical incubation conditions. Microbial growth was evaluated by macroscopic examination of BHI broth turbidity. In conclusion, only the CTZ and MTA pastes showed antimicrobial activity
\end{abstract}

Keywords: deciduous teeth, root canal therapy, microbiology

\section{Introduction}

Pulp therapy is widely used in the treatment of pediatric patients, while attempting to prevent premature exfoliation of the primary teeth. Different techniques and treatments have been proposed in the literature to promote cleansing and sanitation of the root canals of deciduous teeth.

However, the topography of primary teeth root canals, which present accentuated curves and a large number of accessory canals, makes access to and the instrumentation of these teeth more difficult ${ }^{1}$. Besides the anatomical aspect, the process of root resorption in deciduous dentition occurs irregularly and is not always detected radiographically.

This fact makes it difficult to establish an apical limit, both for canal instrumentation and for filling, leading to possible damage of the periodontium and the permanent tooth germ ${ }^{2}$. The overflow of materials presenting nonbiocompatible and nonreabsorbable properties could also affect periapical structures and permit the permanence of these materials in the bone or gingival tissue even after primary tooth exfoliation ${ }^{3}$.

Given the characteristics of deciduous dentition, which impede full manipulation of the root canal, the success of endodontic treatment depends on means that proportion the reduction or elimination of bacteria not only within the root canal, but also in locations that chemical and mechanical preparation are unable to access. Considering the limitations of primary tooth canal instrumentation, the use of filling pastes presenting an antimicrobial capacity represents one of the more important aspects for achieving success in endodontic therapy.

Observing the importance of this aspect of pulp therapy for deciduous dentition, several authors have evaluated the antimicrobial action of materials used in the endodontic treatment of primary teeth; however, the results obtained show significant divergence $e^{4,5,6,7}$.

Therefore, the purpose of this study was to evaluate the antimicrobial activity of different root canal filling pastes used in deciduous teeth, by the direct exposure test.

\section{Materials and Methods}

Six filling pastes were tested (Table 1), in relation to their capacity to inhibit the development of a microbial mixture composed of the following microorganisms: Staphylococcus aureus, ATCC 6538; Enterococcus faecalis, ATCC 29212; Pseudomonas aeruginosa, ATCC 27853; Bacillus subtilis, ATCC 6633; and Candida albicans, ATCC 0231. All the strains isolated and identified by the American Type Culture Collection (ATCC), were cultivated and maintained viable in the CEPO (Centro de Ensino e Pesquisa Odontológica,) in Goiânia (GO), Brazil.

Preservation of the microbial cultures was realized in Brain Heart Infusion Agar (BHIA; Difco Laboratories, Detroit, USA, lot 0350004). After incubation at $37^{\circ} \mathrm{C}$ for 24 hours, microbial cells were suspended in saline solution (Halex Istar, Goiânia, GO, Brazil). The suspension of each strain was adjusted to tube turbidity 1 on the MacFarland scale, at an approximate concentration of $3 \times 10^{8}$ cells $/ \mathrm{mL}$. To prepare the microbial mixture, $1 \mathrm{~mL}$ of inoculum was removed from each microbial suspension and transferred to the same sterilized assay tube, thus, obtaining the test mixture ${ }^{8,9}$. The mixture was used immediately after preparation.

The method used was direct exposure test, in which a total of 54 number 50 absorbent paper points (Tanari, Tanariman Indústria 
Table 1. Canal filling pastes tested.

\begin{tabular}{|c|c|c|c|}
\hline Pastes & Proportion $\mathrm{g} / \mathrm{mL}$ & Composition & Manufacturers \\
\hline Guedes-Pinto & $\begin{array}{l}0.30 \mathrm{~g} \\
0.1 \mathrm{~mL} \\
0.30 \mathrm{~g}\end{array}$ & $\begin{array}{l}\text { Iodoform } \\
\text { Camphorated paramonochlorophenol } \\
\text { Rifocort }^{\circledR}\end{array}$ & $\begin{array}{l}\text { Inodon Laboratório, RS, lot } 1104 \\
\text { Inodon Laboratório, RS, lot } 1004 \\
\text { Medley S.A., SP, lot } 311063\end{array}$ \\
\hline $\mathrm{CTZ}$ & $\begin{array}{l}0.5 \mathrm{~g} \\
0.5 \mathrm{~g} \\
0.0013 \mathrm{~g} \\
0.05 \mathrm{~mL}\end{array}$ & $\begin{array}{l}\text { Chlorophenicol } \\
\text { Tetracycline } \\
\text { Zinc oxide } \\
\text { Eugenol }\end{array}$ & $\begin{array}{l}\text { Quemicetina }{ }^{\circledR} \text { 500, Pharmacia Brasil Ltda, SP, lot H127 } \\
\text { Tetrex }^{\oplus} \text { 500, Bristol Myers Squibb S.A., SP, lot } 1494 \\
\text { SSWhite Artigos Dentários Ltda, RJ, lot } 002 \\
\text { SSWhite Artigos Dentários Ltda, RJ, lot 00A }\end{array}$ \\
\hline Calen $^{\circledR}$ & $0.70 \mathrm{~g}$ & $\begin{array}{l}\text { Calcium hydroxide } \\
\text { Polyethylenglycol } 400\end{array}$ & S.S.White Artigos Dentários Ltda, RJ, lot 003 \\
\hline $\mathrm{L} \& \mathrm{C}^{\circledast}$ & $\begin{array}{l}0.001 \mathrm{~g} \\
0.05 \mathrm{~mL}\end{array}$ & $\begin{array}{l}\text { Calcium hydroxide } \\
\text { Olive oil }\end{array}$ & Dentsply Indústria e Comérco Ltda, RJ, lot 120499 \\
\hline OZE & $\begin{array}{l}0.0013 \mathrm{~g} \\
0.05 \mathrm{~mL}\end{array}$ & $\begin{array}{l}\text { Zinc oxide } \\
\text { Eugenol }\end{array}$ & $\begin{array}{l}\text { S.S.White Artigos Dentários Ltda, RJ, lot } 002 \\
\text { S.S.White Artigos Dentários Ltda, RJ, lot 00A }\end{array}$ \\
\hline MTA & $0.0013 \mathrm{~g}$ & $\begin{array}{l}\mathrm{SiO}_{2}, \mathrm{~K}_{2} \mathrm{O}, \mathrm{Al}_{2} \mathrm{O}_{3}, \mathrm{Na}_{2} \mathrm{O}, \mathrm{Fe}_{2} \mathrm{O}_{3}, \\
\mathrm{SO}_{3}, \mathrm{CaO}, \mathrm{Bi}_{2} \mathrm{O}_{3}, \mathrm{MgO} \text { and several } \\
\text { mineral oxides } \\
\text { Distilled water }\end{array}$ & Ângelus Soluções em Odontologia, PR, lot 1591 \\
\hline
\end{tabular}

Ltda, Manacaru, AM, Brazil, lot 006004P) were used after sterilization in an autoclave $\left(1 \mathrm{~atm}, 121{ }^{\circ} \mathrm{C} / 20\right.$ minutes, Lister horizontal autoclave) and immersion in the microbial suspension for 5 minutes, resulting in contamination ${ }^{6,7}$. Next the points were distributed on Petri dishes containing different pastes that had just been prepared and were completely covered by one of the six pastes. The experimental periods stipulated were 24, 48 and 72 hours. Paper points exactly like those used in the experiments were used for positive and negative controls. In the negative control, sterilized points were placed in tubes containing $7 \mathrm{~mL}$ of Letheen broth (Difco Laboratories, Detroit, USA, lot 143097XA), aimed at proving the sterilization of the same, as revealed by the absence of broth turbidity throughout the experiment. In the positive control, points contaminated by the microbial mixture were placed in tubes containing $7 \mathrm{~mL}$ of Letheen broth (Difco Laboratories), aimed at analyzing the viability of the microbial mixture, as proven by the broth turbidity. At intervals of 24, 48 and 72 hours, 18 absorbent paper points were removed from contact with the pastes and individually transported to $7 \mathrm{~mL}$ of Letheen broth. Next, the broth was incubated at $37^{\circ} \mathrm{C}$ for 48 in a bacteriological heater (ECB 1-3 digital model, Odontobrás, Ribeirão Preto, SP, Brazil) and then analyzed macroscopically to determine the presence or absence of turbidity. All tubes were evaluated to confirm the macroscopic results. Aided by a micropipette (Labex ${ }^{\circledR}$ S/A, Goiânia, GO, Brazil), $100 \mu \mathrm{L}$ of inoculum obtained from the Letheen broth was transferred to assay tubes containing $7 \mathrm{~mL}$ of $\mathrm{BHI}$ broth (Difco Laboratories) and incubated under identical conditions. The final reading was also macroscopic. All the observations were noted for posterior presentation of the results. At all stages of the experiment, aseptic technique was prized, the assays were all conducted by the same technician and the test was performed in triplicate.

\section{Results}

Complete antimicrobial activity was observed for the CTZ and MTA pastes, which presented absence of turbidity for all the experimental periods, whereas the Guedes-Pinto, OZE, Calen ${ }^{\circledR}$ and $\mathrm{L}^{\mathrm{A}} \mathrm{C}^{\circledR}$ pastes presented microbial growth. The positive control confirmed the viability of the microbial mixture and the negative control proved the absence of contamination of the points used (Table 2).
Table 2. Antimicrobial activity using the direct exposure test. Results for each experimental period.

\begin{tabular}{|c|c|c|c|}
\hline \multirow[t]{2}{*}{ Pastes } & \multicolumn{3}{|c|}{ Time } \\
\hline & 24 hours & 48 hours & 72 hours \\
\hline Guedes-Pinto & +++ & +++ & +++ \\
\hline CTZ & --- & --- & --- \\
\hline OZE & +++ & +++ & +++ \\
\hline Calen $^{\circledR}$ & +++ & +++ & +++ \\
\hline MTA & --- & --- & --- \\
\hline $\mathrm{L} \& \mathrm{C}^{\oplus}$ & +++ & +++ & +++ \\
\hline Positive Control & +++ & +++ & +++ \\
\hline Negative Control & --- & --- & --- \\
\hline
\end{tabular}

$+++($ Positive result $)=$ growth presence/inefficacy; and $---($ Negative result $)=$ absence of growth/efficacy. Each sign represents the reading of each sample of the triplicate.

\section{Discussion}

The results demonstrated that Guedes-Pinto paste showed no microbial growth inhibition for any of the experimental periods. Given the use of a mixture of microorganisms and not isolated strains, it could be questioned whether one or more of the microorganisms contained in this mixture might not present resistance to this paste or some of its components. However, Amorim et al. (2006) ${ }^{6}$ reported the inhibition of microbial growth by Guedes-Pinto paste after 24 hours, using an identical methodology.

CTZ paste completely inhibited growth of the microbial mixture from the onset of the experimental periods. This result corroborates reports found in the literature ${ }^{6}$. CTZ paste, despite the limited number of studies published in the literature, is recommended as a root canal filling material in deciduous dentition by Brazilian Dental schools ${ }^{10,11}$. However, the clinical use of this paste would require further study, so that other properties essential to a root canal filling material of primary teeth can be identified, such as biocompatibility with periapical tissue and the ideal proportion of its components that would make it as noncytotoxic as possible without unduly affecting its antimicrobial capacity. 
Concerning the results obtained using zinc oxide eugenol (ZOE), this paste showed no inhibition of microbial growth throughout the experimental periods. Even though ZOE is still the most commonly used material in the endodontic treatment of deciduous teeth in the USA and the second choice for this end according to Brazilian Dental schools, its leaves much to be desired regarding the ideal characteristics of a canal filling material in primary teeth, given the absence of biological compatibility, the fact that its is strongly irritant to periapical tissue and the fact that it does not accompany root canal development in deciduous dentition ${ }^{10,11,12,13}$.

Certainly, among the materials tested in the present work, calcium hydroxide is the most studied in relation to its antimicrobial action $^{6,9,14,15}$. In this study, calcium hydroxide was tested in the form of two commercially available compounds: Calen ${ }^{\circledR}$ paste, basically composed of calcium hydroxide and polyethylenglycol 400; and L\&C paste, composed of calcium hydroxide mixed with olive oil as a vehicle. Calen ${ }^{\circledR}$ and L\&C pastes presented unfavorable results in the method used and against the microbial mixture tested, for all the experimental periods. Calen ${ }^{\circledR}$ paste presented similar results to those found in the literature ${ }^{16}$.

MTA paste inhibited the growth of the microbial mixture over the three experimental periods. It is possible that MTA in direct contact with the mixture was a determining factor for the antimicrobial action of this material, as shown by the complete absence of microbial growth. According to reports in the literature, when tested by the agar diffusion method, this material presented divergent results, in some studies it presented diffusion halos in the medium and did not inhibit the microorganisms tested, in others it presented significant microbial inhibition zones ${ }^{17,18}$.

Based on the literature consulted and the results obtained, we believe that further studies are required, so that a material that presents the greatest number of characteristics that approach the ideal for use in root canal fillings in deciduous dentition can be established.

\section{Conclusions}

In accordance with the methodology used and the results obtained, it can be concluded that only the CTZ and MTA pastes presented antimicrobial activity against the microbial mixture over the different experimental periods.

\section{References}

1. Hibbard ED, Ireland RL. Morphology of root canal of the primary molar teeth. J. Den. Child. 1957; 24(4):250-7.

2. Bengston AL, Bengston NG. Efeito da instrumentação endodôntica em molares decíduos. Rev. Assoc. Paul Cir. Dent. 1993; 47(5):1149-54.

3. Faraco Jr IM, Percinoto C. Avaliação de duas técnicas de pulpectomia em dentes decíduos. Rev. Assoc. Paul Cir. Dent. 1998; 52(5):400-4.
4. Bonow MLM, Guedes-Pinto AC, Bammann LL. Antimicrobial activity of drugs used in pulp therapy of deciduous teeth. Braz. Endod. J. 1996; $1(1): 44-8$.

5. Silva LAB, Nelson-Filho P, Faria G, Souza-Gugelmin MCM, Ito IY. Bacterial profile in primary teeth with necrotic pulp and periapical lesion. Braz. Dent. J. 2006; 17(2):144-8.

6. Amorim LFG, Toledo OA, Estrela CRA, Decurcio DA, Estrela C. Antimicrobial analysis of different root canal filling pastes used in pediatric dentistry by two experimental methods. Braz. Dent. J. 2006; 17(4):317-22.

7. Silva CM, Candelária LFA, Bombana AC. Estudo comparativo da ação antimicrobiana entre cinco pastas de obturação de canais radiculares de dentes decíduos. J. Bras. Odontopediatr. Odontol. Bebê 2002; 5(28):502-10.

8. Pazelli LC, Freitas AC, Ito IY, Souza-Gugelmin MCM, Medeiros AS, Nelson-Filho P. Prevalence of microorganisms in root canals of human deciduous teeth with necrotic pulp and chronic periapical lesions. Pesqui. Odontol. Bras. 2003; 17(4):367-71.

9. Estrela C, Estrela CRA, Bammann LL, Pecora JD. Two methods to evaluate the antimicrobial action of calcium hydroxide paste. J. Endod. 2001; 27(12):720-3.

10. Kramer PF, Faraco-Junior IM, Feldens CA. Estado atual da terapia pulpar nas Universidades Brasileiras, Pulpotomia e pulpectomia em dentes decíduos. J. Brás. Odontopediatr. Odontol. Bebê 2000; 3(3):222-30.

11. Corrêa-Brusco EH, Perussolo B, Scapin HLC, Ferreira SLM. Procedimentos e substâncias empregadas por Faculdades de Odontologia Brasileiras na terapia endodôntica de dentes decíduos pulpectomizados. J. Bras. Odontopediatr. Odontol. Bebê 2002; 5(23):35-46.

12. Primosch RE, Glomb TA, Jerrell RG. Primary tooth pulp therapy as taught in predoctoral pediatric dental programs in the United States. Pediatr. Dent. 1997; 19(2):118-22.

13. Sadrian R, Coll JA. A long-term followup on the retention rate of zinc oxide eugenol filler after primary tooth pulpectomy. Pediatr. Dent. 1993; 15(4):249-52.

14. Estrela C, Bammann LL, Estrela CRA, Silva RS, Pecora JD. Antimicrobial and chemical study of MTA, portland cement, calcium hydroxide paste, sealapex and dycal. Braz. Dent. J. 2000; 11(1):3-9.

15. Gomes BPFA, Ferraz CCR, Garrido FD, Rosalen PL, Zaia AA, Teixeira FB, Souza-Filho FJ. Microbial susceptibility to calcium hydroxide pastes and their vehicles. J. Endod. 2002; 28(11):758-61.

16. Dotto SR, Travassos RMC, Ferreira R, Santos R, Wagner M. Avaliação da ação antimicrobiana de diferentes medicações usadas em endodontia. Rev. Odonto. Ciência. 2006; 21(53):266-9.

17. Torabinejad M, Hong CU, Pit Ford TR, Kettering JD. Antibacterial effects of some root end filling materials. J. Endod. 1995; 21(8):403-6.

18. Stowe TJ, Sedgley CM, Stowe B, Fenno JC. The effects of chlorhexidine gluconate $(0.12 \%)$ on the antimicrobial properties of tooth-colored ProRoot mineral trioxide aggregate. J. Endod. 2004; 30(6):429-31. 